\title{
Sickness absence in diabetic employees
}

\author{
A Škerjanc
}

\begin{abstract}
Objectives-To compare sickness absence among diabetic and non-diabetic employees.

Methods-A cross sectional case-control study was conducted in a random sample of 400 diabetic employees 21-50 years old from Ljubljana that compared their sickness absence in the year 1996 with sickness absence of non-diabetic employees matched by sex, age, and occupation. Sickness absence was compared in total and also in subgroups formed by sex, age, occupation, and disability. Nonparametric statistics were used $\left(\chi^{2}\right.$ test, Wilcoxon matched pairs test).

Results-The randomised sample consisted of $61.2 \%$ of men (245) and $38.8 \%$ of women (155) with a mean age of 42.5 years. Unskilled workers made up $30.2 \%$ of employees, and less than $16.4 \%$ were highly educated. Among diabetic employees there were $7.0 \%$ disabled and among non-diabetic employees $2.0 \%$. The mean frequency of sickness absences of diabetic employees was 0.89 times in the year 1996 (95\% confidence interval $(95 \% \mathrm{CI}) 0.70$ to 1.08 ), and of non-diabetic employees 0.56 times $(95 \%$ CI 0.47 to 0.65$), p=0.01$. The mean total duration of sickness absence of diabetic employees was 31.71 days $(95 \%$ CI 24.86 to 38.57 ), of non-diabetic employees 16.57 days (95\% CI 11.72 to 21.42 ), $\mathrm{p}<0.01$. Differences were also found in subgroups but the size of subgroups was not sufficient to detect significant differences. Conclusions-The study confirmed that diabetes affects the ability to work. Appropriate work and good control of the disease are important to prevent long term complications.

(Occup Environ Med 2001;58:432-436)
\end{abstract}

Keywords: sickness absence; diabetes mellitus

Sickness absence is defined in Slovenia as temporary absence from work because of illness, injury, or the need to care for a family member, and in some extreme cases, as isolation, accompaniment of a family member, visits to the physicians, or waiting for the decision of the board of examiners in the Institute of Pension and Disability Insurance, etc. ${ }^{1}$ Sickness absence is the negative health indicator which is most often used in records for estimation of workers' health. As it is affected by many causes and reflects adaptation of workers to the demands and risks of work and also environmental and social circumstances, it illustrates the disturbance of the dynamic balance between the worker, workplace, and working environment. $^{2-4}$ The right to absence from work on grounds of illness comprises two particular rights-namely, the right of an employee to be absent from work for justified reasons and the right to receive adequate compensation for missed salary. ${ }^{15}$ The compensation is shared by the person's employer and by the Health Insurance Institute. The Health Insurance Institute states that although temporary health related absenteeism is justified by illnesses, it is above all a social problem. The Institute estimates that only a few of the factors that cause temporary absence from work are actually related to the health of employees. To a large extent sickness absence is affected by factors related to the person's working, living, and social environment - such as motivation to work, conditions of the workplace, rate of employment, protection and safety at work, the level of education, and interpersonal relations. ${ }^{6}$

One of the important and increasing chronic diseases in modern times, which can affect and limit the working ability of workers, is diabetes mellitus. ${ }^{78}$ This differs considerably from other chronic diseases. Its treatment requires discipline and self monitoring and the success of treatment depends mostly on the patients themselves. $^{9}$

In 1995 it was estimated that 75000 people in the Republic of Slovenia had diabetes mellitus, which represented $3.75 \%$ of the population. Each year 4500 people get diabetes. ${ }^{10}$ It has been estimated that 13000 employees among the working population are diabetic. ${ }^{11}$ Much of the international research has not clarified how sickness absence compares between diabetic and non-diabetic employees. ${ }^{4}{ }^{912-18}$ Each piece of research has its own limitations: some included only patients from diabetic clinics, ${ }^{13}$ in some, diabetic employees selected their controls, ${ }^{12}{ }^{14}$ others did not show statistical analysis of their data. ${ }^{4}{ }^{18}$ Some studies had relatively small samples. ${ }^{13} 16$ In Slovenia not much is known about sickness absence of diabetic employees, but we suppose that morbidity of diabetic patients occurs more often than morbidity of non-diabetic subjects. ${ }^{19}$

Labour legislation in most of the world does not consider diabetic workers separately, rather, recommendations are simply proposed. However, the associations of diabetic workers in the United States, the United Kingdom, and Germany have secured the legal right to work. Diabetic subjects must not be discriminated against at work and only traffic legislation prohibits diabetic workers from taking some jobs. $^{2021}$ Recommendations of the World Health Organisation are similar. ${ }^{22}$ Nevertheless, employers resist employing diabetic people because of the expected increase in sickness absence. ${ }^{11} 17$

The study objective was therefore to compare sickness absence between diabetic and 
non-diabetic employees in Ljubljana (the capital of the Republic of Slovenia) The findings may help people with diabetes mellitus in seeking and keeping jobs and integrating into society.

\section{Methods}

EMPLOYEES AND METHODS

This cross sectional case-control study compared sickness absence of diabetic employees in Ljubljana in 1996 with the sickness absence of non-diabetic employees matched by sex, age, and occupation. The population from which the random sample was taken consisted of all employees from the city of Ljubljana, born between the years 1946 and 1975, in the register of insurees in the Health Insurance Institute of Slovenia (insurance is compulsory for all the people of Slovenia).

The random sample comprised two groups of employed insurees from Ljubljana who were 21-50 years old in the year 1996: 400 diabetic employees and 400 non-diabetic employees. Four hundred pairs were established so that each pair was matched by sex, age, and occupation. All the people with diabetes from Ljubljana were treated by the end of 1996 in three centres - in the Clinical Centre of Ljubljana and in two outpatient clinics for diabetic patients. A list of 1230 people with diabetes from these three centres was obtained who were 21-50 years old at the end of December 1996. At the information centre of the Health Insurance Institute, 1076 people with diabetes were employed in 1996 out of the list of 1230 . On the computer in this centre, the random sample of 400 from this list of 1076 diabetic employees was chosen. From the register of insurees the occupation in 1996 was also assessed for each chosen case. From the same register a control was found for each subject of the sample - a non-diabetic employee, matched by sex, age, and occupation, also from Ljubljana. For each of the 800 employees data were given about the general physician where medical documentation and data about sickness absence was gathered.

\section{DATA COLLECTION}

A questionnaire was filled in for each employee from two sources of data.

The Health Insurance Institute provided data for each employee about sex, age, occupation (unskilled workers, construction workers, shop assistants, skilled workers, clerks, professional drivers, teachers, medical staff, and lawyers, journalists, and economists) and disability (non-disabled employees, disabled employees). Disabled employees are those who, because of illness, injuries at work, occupational diseases, or injuries out of work, with or without professional rehabilitation, held another suitable job after they had been assessed by the Commission for disabled people (board of examiners) in the Pension and Disability Insurance Department. ${ }^{23}$

From medical documentation, held by the general physicians of both groups of employees - cases (diabetic employees) and controls (non-diabetic employees) - a questionnaire was filled in about the frequency and total duration of sickness absence in 1996, about the cause of sickness absence by groups from the ninth revision of the international classification of diseases, injuries, and causes of deaths (ICD-9 from the year 1975), and about the presence of long term complications of diabetes mellitus.

\section{ANALYSIS AND STATISTICAL METHODS}

The data were analysed according to established non-parametric statistics ( $\chi^{2}$ test, Wilcoxon matched pairs test). The differences were taken to be significant if the expected degree of risk was $<0.05$.

This research was approved by the ethics committee of the Ministry of Health of the Republic of Slovenia on 30 May 1997.

\section{Results}

DESCRIPTION OF THE SAMPLE

The group of diabetic employees (400) and the control group of non-diabetic employees (400) each comprised 245 men $(61.2 \%)$ and 155 women $(38.8 \%)$. The mean age of employees of both groups was 42.5 years. Most of them were in the range $41-50$ years $(283(70.7 \%))$, others were in the $31-40$ range $(86(21.5 \%))$ or the $21-30$ range $(31(7.8 \%))$.

Most employees were unskilled workers (121 $(30.2 \%)$ ), others were skilled workers (69 (17.2 $\%))$, clerks (65 (16.2\%)), lawyers, journalists, and economists (37 (9.7\%)), shop assistants (36 $(9.0 \%))$, professional drivers $(29(7.2 \%))$, construction workers $(14(3.5 \%))$, teachers $(14$ $(3.5 \%))$, and medical staff $(13(3.2 \%))$. Less than $16.4 \%$ (teachers, medical staff, lawyers, journalists, and economists) were highly educated. Among men there were $71.2 \%$ working as unskilled workers, construction workers, skilled workers, or drivers, whereas among women there were $70.3 \%$ working as shop assistants, clerks, teachers, medical staff, lawyers, journalists, and economists.

Among diabetic employees there were 28 disabled $(7.0 \%)$, and among non-diabetic employees there were eight disabled $(2.0 \%)$ $\left(\chi^{2}=11.6347, \mathrm{p}<0.001\right)$.

Diabetic employees were on average likely to have sickness absence 0.89 times (95\% CI 0.70 to 1.08$)$ in the year 1996, non-diabetic employees 0.56 times ( $95 \%$ CI 0.47 to 0.65 ), $(Z=-2.4167, \mathrm{p}=0.01)$. Most employees, 234 diabetic $(58.5 \%)$ and 260 non-diabetic $(65.0 \%)$ had no sickness absence $\left(\chi^{2}=15.9379\right.$, $\mathrm{p}<0,001)$. Among diabetic employees the greatest number of sickness absences was 11 , whereas it was six among non-diabetic employees. Frequency of sickness absence (number of sickness absences per employee) in 1996 is presented in table 1 .

The mean total duration of sickness absence in the observed year was, for diabetic employees, 31.71 days (95\% CI 24.86 to 38.57 ), whereas it was 16.57 days (95\% CI 11.72 to 21.42) for non-diabetic employees $(Z=-2.6641, \mathrm{p}=0.008)$. As already mentioned most employees were not absent from work because of illness, injury, or care for a family 
Table 1 Frequency of sickness absence

\begin{tabular}{|c|c|c|c|c|}
\hline \multirow[b]{2}{*}{ Group } & \multicolumn{2}{|c|}{ Frequency (95\% CI) of absences/employee } & \multirow[b]{2}{*}{$Z$ Value } & \multirow[b]{2}{*}{ p Value } \\
\hline & Diabetic employees & Non-diabetic employees & & \\
\hline Total & $0.89(0.70$ to 1.08$)$ & $0.56(0.47$ to 0.65$)$ & -2.4167 & 0.01 \\
\hline \multicolumn{5}{|l|}{ By sex: } \\
\hline Men & $0.97(0.76$ to 1.18$)$ & $0.44(0.34$ to 0.54$)$ & -2.7800 & 0.005 \\
\hline Women & $0.86(0.66$ to 1.07$)$ & 0.75 (0.58 to 0.93$)$ & -0.3876 & 0.70 \\
\hline \multicolumn{5}{|l|}{ By age: } \\
\hline $21-30$ & $0.77(0.16$ to 1.39$)$ & $0.65(0.32$ to 0.97$)$ & -0.6950 & 0.49 \\
\hline $31-40$ & $1.14(0.77$ to 1.50$)$ & $0.63(0.40$ to 0.86$)$ & -2.3898 & 0.02 \\
\hline $41-50$ & $0.83(0.64$ to 0.95$)$ & $0.53(0.43$ to 0.64$)$ & -1.7322 & 0.08 \\
\hline \multicolumn{5}{|l|}{ By occupation: } \\
\hline Unskilled workers & $0.97(0.68$ to 1.26$)$ & $0.64(0.47$ to 0.81$)$ & -0.5127 & 0.60 \\
\hline Construction workers & $1.00(0.01$ to 1.99$)$ & $0.07(-0.08$ to 0.23$)$ & -2.2101 & 0.03 \\
\hline Shop assistants & $0.89(0.51$ to 1.27$)$ & $0.53(0.28$ to 0.78$)$ & -1.2036 & 0.23 \\
\hline Skilled workers & $1.12(0.78$ to 1.47 & $0.58(0.34$ to 0.82$)$ & -1.6351 & 0.09 \\
\hline Clerks & $0.68(0.31$ to 1.04$)$ & $0.55(0.28$ to 0.83$)$ & -0.4172 & 0.68 \\
\hline Drivers & $0.93(0.39$ to 1.47$)$ & $0.48(0.20$ to 0.76$)$ & -1.3725 & 0.17 \\
\hline Teachers & $0.93(0.13$ to 1.73$)$ & $0.86(0.26$ to 1.45$)$ & -0.1760 & 0.86 \\
\hline Medical staff & $0.77(0.33$ to 1.21$)$ & $0.69(0.18$ to 1.21$)$ & -0.3884 & 0.70 \\
\hline $\begin{array}{l}\text { Lawyers, journalists, } \\
\text { economists }\end{array}$ & $0.59(0.25$ to 0.93$)$ & $0.44(0.16$ to 0.71$)$ & -0.5742 & 0.57 \\
\hline \multicolumn{5}{|l|}{ By disability: } \\
\hline Non-disabled & $0.82(0.68$ to 0.96$)$ & $0.55(0.46$ to 0.64$)$ & -2.0385 & 0.04 \\
\hline Disabled & $1.82(0.87$ to 2.77$)$ & $1.13(-0.01$ to 2.26$)$ & -0.4006 & 0.69 \\
\hline
\end{tabular}

Table 2 Mean total duration of sickness absence

\begin{tabular}{|c|c|c|c|c|}
\hline \multirow[b]{2}{*}{ Group } & \multicolumn{2}{|c|}{ Mean ( $95 \%$ CI) total duration of absenteeism (days) } & \multirow[b]{2}{*}{$Z$ Value } & \multirow[b]{2}{*}{$p$ Value } \\
\hline & Diabetic employees & Non-diabetic employees & & \\
\hline Total & 31.71 (24.86 to 38.57$)$ & 16.57 (11.72 to 21.42$)$ & -2.6641 & 0.008 \\
\hline \multicolumn{5}{|c|}{$x^{2}$} \\
\hline Men & $.52(18.52$ to 34 . & 12.35 (5.62 to 19.08$)$ & -2.5539 & 0.01 \\
\hline Women & 2 to 52.23 ) & $23.24(14.07$ to 32.41$)$ & -1.2256 & 0.22 \\
\hline \multicolumn{5}{|c|}{ 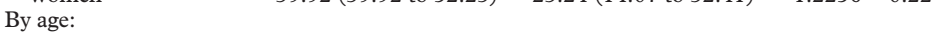 } \\
\hline $21-30$ & $.32(3.96$ to 44.68$)$ & 10.84 (1.81 to 19.86$)$ & -0.4955 & 0.62 \\
\hline $31-40$ & $.23(15.43$ to 35.04$)$ & 15.17 (4.87 to 25.48$)$ & -2.5630 & 0.01 \\
\hline $41-50$ & $4.49(25.50$ to 43.48$)$ & $17.62(11.57$ to 23.68$)$ & -1.8858 & 0.05 \\
\hline \multicolumn{5}{|l|}{ By occ } \\
\hline Unskilled workers & $34.71(21.97$ to 47.45$)$ & 25.20 (12.66 to 37.74$)$ & -0.4737 & 0.64 \\
\hline Const & $30.38 \mathrm{r}>\mathrm{C}$ & $0.79(-0.91$ to 2.48$)$ & -2.2955 & 0.02 \\
\hline Shop & to 63.25$)$ & $11.75(3$ & -1.0193 & 0.31 \\
\hline Skilled & & & -1.3461 & 0.18 \\
\hline Clerks & 88 & $9.28(4$ & -0.8701 & 0.38 \\
\hline Driver & 72 & $15.55(1$ & -1.4577 & 0.15 \\
\hline Teache & $31.85)$ & $12.57(0$ & -0.4245 & 0.67 \\
\hline Medical staff & $69.92(4.29$ to 135 . & $29.39(-7.45$ to 66.21$)$ & -0.8640 & 0.39 \\
\hline $\begin{array}{l}\text { Lawyers, journalists, } \\
\text { economists }\end{array}$ & & 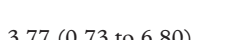 & & \\
\hline By disa & $13.46(3.02$ to 27.30$)$ & 3.11 & & 0. \\
\hline Non-disabled & 180 & 15.9 & -2.2452 & 0.02 \\
\hline Disabled & 78.68 (38.32 to 119.04$)$ & $46.75(-2.50$ to 96.02$)$ & 0.5179 & 0.60 \\
\hline
\end{tabular}

member. In each group there were also three employees who had sickness absence from work for the whole year. The mean total duration of sickness absence (days of sickness absences per employee) in 1996 is presented in table 2 .

Long term complications of diabetes were present in 98 employees $(24.5 \%)$. The others did not have any registered. The most frequent long term complication was diabetic retinopathy (62 or $15.5 \%$ of the diabetic employees). The mean frequency of sickness absence of the employees without or with long term complications did not differ significantly: diabetic employees without long term complications on average were absent through sickness 0.84 times (95\% CI 0.68 to 1.00 ), and those with long term complications 1.05 times (95\% CI 0.71 to 1.39$),(Z=-1.3277, \mathrm{p}=0.18)$. Diabetic employees without long term complications of diabetes were on average absent through sickness for 26.98 days (95\% CI 20.02 to 33.97), but those with long term complications were on average absent through sickness for 46.31 days (95\% CI 28.80 to 63.82), $(Z=-1.7822, \mathrm{p}=0.07)$.

The causes of sickness absence are summarised in table 3. In both groups most days were lost because of diseases of the limbs, followed by injuries. Diseases of the cardiovascular system took third place in diabetic employees and mental disorders in non-diabetic employees.

\section{Discussion}

The results suggest that sickness absence of diabetic employees is greater than that of nondiabetic employees.

Most workers in both groups had no sickness absence $(58.8 \%$ of diabetic employees and $65.0 \%$ of non-diabetic employees). In the general population only $30 \%-40 \%$ of employees usually have no sickness absence. ${ }^{24}$ This difference could be because diabetic employees are usually not exposed to intense physical loads or shift work. Diabetic employees are a group that has a positive attitude towards work, but among the groups is a subgroup of employees who more often have sickness absence.

Table 3 Mean total duration of sickness absence in diabetic and non-diabetic employees by the ICD-9 (1975)

\begin{tabular}{|c|c|c|c|c|c|c|c|}
\hline \multirow[b]{2}{*}{ Group } & \multirow{2}{*}{$\begin{array}{l}\text { Code of } \\
\text { diagnosis }\end{array}$} & \multirow[b]{2}{*}{ Diagnosis } & \multicolumn{2}{|c|}{ Mean (95\% CI) total duration of sickness absence (days) } & \multirow[b]{2}{*}{$Z$ value } & \multirow[b]{2}{*}{ p Value } & \multirow{2}{*}{$\begin{array}{l}\text { Diabetic } v \\
\text { non-diabeti }\end{array}$} \\
\hline & & & Diabetic employees & Non-diabetic employees & & & \\
\hline I & $001-139$ & Infectious diseases & $1.73(0.62$ to 2.84$)$ & $0.56(0.30$ to 0.82$)$ & -1.0384 & NS & $3.0: 1$ \\
\hline II & $140-239$ & Neoplasm & $0.16(-0.10$ to 0.41$)$ & $1.12(0.72$ to 2.96$)$ & -0.0050 & NS & $0.1: 1$ \\
\hline III & $240-279$ & Endocrine diseases & $1.64(0.50$ to 2.78$)$ & $0.64(-0.56$ to 1.83$)$ & -3.6122 & $<0.001$ & $2.6: 1$ \\
\hline IV & $280-289$ & Haematological disorders & $0.12(-0.11$ to 0.35$)$ & $0.56(-0.54$ to 1.65$)$ & -0.0018 & NS & $0.2: 1$ \\
\hline $\mathrm{V}$ & $290-319$ & Mental disorders & $2.20(0.21$ to 4.18$)$ & $1.64(-0.24$ to 3.52$)$ & -0.4322 & NS & 1.3:1 \\
\hline VI & $320-389$ & Neural and sensor disorders & $1.88(-0.04$ to 3.80$)$ & $0.23(0.07$ to 0.39$)$ & -1.0533 & NS & $8.2: 1$ \\
\hline VII & $390-459$ & Cardiovascular diseases & $3.50(0.62$ to 6.37$)$ & $0.38(0.09$ to 0.68$)$ & -0.6939 & NS & $9.2: 1$ \\
\hline VIII & $460-519$ & Respiratory diseases & $2.29(1.09$ to 3.49$)$ & $1.05(0.62$ to 1.47$)$ & -0.8367 & NS & $2.2: 1$ \\
\hline IX & $520-579$ & Gastrointestinal diseases & $2.14(-0.04$ to 4.31$)$ & $0.83(0.25$ to 1.40$)$ & -0.9571 & NS & $2.6: 1$ \\
\hline $\mathrm{X}$ & $580-629$ & Urogenital diseases & $1.32(-0.51$ to 3.15$)$ & $0.33(0.11$ to 0.54$)$ & -0.1961 & NS & $4.0: 1$ \\
\hline XI & $630-676$ & Complications of pregnancy & $3.06(1.12$ to 4.99$)$ & $1.15(-0.16$ to 2.46$)$ & -2.0126 & $<0.05$ & $2.7: 1$ \\
\hline XII & $680-709$ & Skin diseases & $0.48(-0.34$ to 1.30$)$ & $1.04(-0.77$ to 2.84$)$ & -0.3241 & NS & $0.5: 1$ \\
\hline XIII & $710-739$ & Diseases of limbs & $7.34(3.84$ to 10.84$)$ & $3.97(1.40$ to 6.53$)$ & -1.0980 & NS & $1.8: 1$ \\
\hline \multirow[t]{5}{*}{ XVII } & 800-999 & Injuries & $3.71(1.27$ to 6.15$)$ & $3.08(1.33$ to 4.84$)$ & -0.2782 & NS & $1.2: 1$ \\
\hline & V60 & Care & $0.02(-0.02$ to 0.06$)$ & $0.02(-0.01$ to 0.04$)$ & -0.5752 & NS & $1.0: 1$ \\
\hline & V70 & Visits to the physician & $0.05(-0.01$ to 0.1$)$ & $0.01(-0.01$ to 0.02$)$ & -2.3239 & $<0.05$ & $5.0: 1$ \\
\hline & V77.1 & Visits to the diabetic specialist & $0.10(0.06$ to 0.14$)$ & 0.00 & -5.0762 & $<0.001$ & \\
\hline & & Total & $31.71(24.86$ to 38.57$)$ & $16.57(11.72$ to 21.42$)$ & -2.6641 & $<0.01$ & $1.9: 1$ \\
\hline
\end{tabular}


Generally, diabetic employees were absent more often and for longer than non-diabetic employees. Some authors have presented similar conclusions, ${ }^{414} 18$ but others have shown similar sickness absence in diabetic and non-diabetic workers. However, their groups were small. ${ }^{13}{ }^{16}$ Extremely long sickness absence is a serious problem in diabetic employees. However, the mean total duration of sickness absence per diabetic employee as well as per non-diabetic employee is probably much longer in our country than it is in the countries of the European Union-the consequence of very broad social rights with no limits in total duration of sickness absence.

A significant difference in frequency of sickness absence was found between groups of men (diabetic and non-diabetic), not between the groups of women. Probably, after chronic health impairment, conditions at work contribute to a greater sickness absence in employed men with diabetes mellitus. Because of their acute impairment they may not have any chance of further compensation, so they have to use sickness absence (construction workers). Women are employed in administration and educational matters more often than men. Thus, employed women with diabetes have more opportunity to carry out blood glucose self monitoring and ensure they get good nutrition. Some authors think that diabetes is a leading cause of the growing tendency in men towards sickness absence. ${ }^{3}$

The frequency of sickness absence started to differ between diabetic and non-diabetic employees in the age group $31-40$ years. This disease seems to cause more frequent sickness absence early in a working career. ${ }^{13}$

Among studied occupations, trends for differences between diabetic employees and non-diabetic employees existed in all groups, whereas significant differences were found only between diabetic and non-diabetic construction workers. The number of people in the subgroups was probably not sufficient to detect significant differences. Stresses, risks, and demands of the workplace could affect the frequency of sickness absence as could other factors, particularly health status. ${ }^{25}$ Sickness absence among medical staff of both groups was surprisingly high. This has been found in other research and indicates that the greatest influence on disability, besides strained socioeconomical conditions, is caused by a stressful situation at work. Intense loads, unsettled environment at work and at home, and bad mutual relations have harmful influences on workers' feelings, satisfaction, and state of health. ${ }^{12}{ }^{26-29}$

Disabled workers were absent through sickness more than non-disabled workers of both groups. But the difference between diabetic and non-diabetic employees was significant only between the groups of non-disabled employees. Most likely, the estimates of acquired disability by the Commission for disabled people in Slovenia consider disabled employees with and without diabetes similarly, and may help diabetic workers to perform their job better.
Sickness absence is also one of the indicators of the quality of care for diabetic subjects. ${ }^{30}$ Sickness absence is not necessarily identical to morbidity, yet it usually reflects the level of seriousness of the disease. ${ }^{15}$ The presence of long term complications of diabetes (macrocirculation, diabetic retinopathy, and diabetic nephropathy) seems to affect the mean duration of sickness absence. The variability of the mean total duration of sickness absence for the causes classified by the ICD was very large so that significant differences between diabetic employees and non-diabetic employees were found only in groups of endocrine diseases (diabetes is in this group), complications of pregnancy (employed women with diabetes are given sickness absence in Slovenia for the entire pregnancy because of the importance of well controlled diabetes for the development of the child), and visits to physicians or diabetic specialists. We can blame only a small proportion of all diabetic employees for the greater sickness absence among diabetic workers. Other authors emphasise that at most $30 \%$ of diabetics were responsible for the high sickness absence; the other $70 \%$ definitely had as good work efficiency as non-diabetic employees. ${ }^{9}$ Perhaps we could say this of those without long term complications of diabetes.

The rate of disability is one of the most convincing indexes of ill health besides sickness absence. The proportion of disabled employees was found to be higher among diabetic than non-diabetic employees. This suggests that diabetic people have impairments that stop them from performing their job all the time to normal work standards without threatening their health. The causes are long term complications of diabetes mellitus. ${ }^{7}$ Long term complications of diabetes also make it a serious and expensive disease. ${ }^{79} 3132$

Diabetes affects the ability to work. As diabetes mellitus progresse $\mathrm{s}^{33-35}$ and as occupation will remain the same or become an even more important basis for economic existence and a therapeutic need, ${ }^{36}$ it seems necessary to study sickness absence in diabetes in more detail and in subgroups. The size of these groups should be greater to have power to detect significant differences.

1 The law on health care and health insurance. Official Gazette RS 9/92:577-601.

2 Modic S. Ocenjevanje zmožnosti za delo z ekonomskega, druž benega in medicinskega vidika. Zdrav Vestn 1977;46: 13-7

3 Šarić M. Problemi utvrdjivanja medicinskih kriterija pri ocenjivanju privremene nesposobnosti za rad. In: Modic S, ed. Seminar Spremljanje, proučevanje in obvladovanje bolnied. Seminar Spremljanje, proučevanje in obvladovanje bolnškega staleza in invalidnosti (prevencija). Ljubljana, Slove

4 Moore RH, Bushbom RL. Work absenteeism in diabetics. Moore RH, Bushbom RL.
Diabetes 1974;23:957-61.

5 The statute on compulsory health insurance. Official Gazette RS 79/94:4488-520

6 Annual report of the Health Insurance Institute of Slovenia. Ljubljana, Slovenia: HIIS, March 1997:28-30.

7 Kenneth EQ jr. Economics and social cost of diabetes. In: Kehn CR, Weir CG, eds. Foslin's diabetes mellitus, 13th ed. Philadelphia: Lea and Febiger, A Waverly Company, 1994 . 586-604.

8 Pfeifer EF, Reaven GM, eds. Diabetes care and research in Europe. Third European meeting for the implementation of the St Vincent Declaration. Athens, Greece: 29 March-1 April St Vincent Dec
1995:7-79.

9 Gruber W, Lander T, Leese B, et al. The economics of diabetes and diabetes care. A report of diabetes health economics study group. Brussels: IDF, 1997:1-115. 
10 Koselj M. Epidemiologija sladkorne bolezni v Sloveniji. In: Medvešček M, ed. Strokovna izhodišč za nacionalni načrt zdravstvenega varstva bolnikov s sladk

11 Koselj M. Sladkorna bolezen in izmensko delo. In: Bilban $\mathrm{M}$, ed. Strokovno srečanje Nočno in izmensko delo. Cerkno, Slovenia: SZD, IMDPŚ, ZVD, 22-23 November 1996:7780.

12 Robinson N, Yateman NA, Protopapa LE, et al. Employment problems and diabetes. Diab Med 1990;7:16-22.

13 Waclawski ER. Sickness absence among insulin treated diabetic employees. Diabet Med 1990;7:41-4.

14 Griffiths RD, Moses RG. Diabetes in the workplace. Employment experiences of young people with diabetes mellitus. Med $\mathcal{F}$ Aust 1993;158:169-71.

15 Julius U, Gross P, Hanefeld M. Work absenteeism in type 2 diabetes mellitus and results of the prospective diabetes intervention study. Diab Metab 1993;19:202-6.

16 Poole CJM, Gibbons D, Cawert IA. Sickness absence in diabetic employees at a large engineering factory. Occup diabetic employees at a large engin

17 Lloyd AC, Williams ZV, Lancey LA, et al. Impact of type II diabetes on employment status and work productivity. Presented at 32nd annual meeting of the European association for the study of diabetes. Vienna, Austria: EASD, 1996.

18 Welch RA. Employment of diabetics in a post office region. Fournal of the Society of Occupational Medicine 1986;36:805.

19 Medvešček M. Socialno ekonomsko breme sladkorne bolezni. In: Medvešček M, ed. Strokovna izhodišča za nacionalni načrt zdravstvenega varstva bolnikov s sladkorno boleznijo. Ljubljana, Slovenia: Univerzitetni klinični Center Ljubljana, October 1995:7-8.

20 Atwell C. The effects of health on work. In: Bamford M, ed. Work and health. London: Chapman and Hall, 1995:39-58.

21 Pravilnik o zdravstvenih pogoiih ki jih morajo izpolnjevati vozniki motornih vozil. Official Gazette SFRF. Ljubljana, vozniki motornih vozil. Official Gazette SFRf. Ljubljana,

22 World Health Organisation. Study group on diabetes mellitus. Geneva: WHO, 1985:9-98. (Technical report series No Geneva:

23 The law on pension and disability insurance. Official Gazette RS 12/92:744-69.

24 The Swedish Ministry of Health and Social Affairs. Health in Sweden. Stockholm: 1982:31-47.

25 Ribić Z. Uzroci bolovanja. In: Šarić M, ed. Bolovanje, priruč nik za ocjenu privremene nesposobnosti za rad. Zagreb, Institut za medicinska istraživanja i medicinu rada, 1982:21-45.
26 Kumelj GM. Raven in dinamika invalidiziranja v Kliničnem centru Ljubljana, 1985-1991. Specialistična naloga Ljubljana, Slovenia. Univerza v Ljubljani, Medicinska fakulteta in Klinični center Ljubljana, Inštitut za medicino dela, prometa in športa, januar 1994:17-68.

27 Šamu J, Turk V, Megušar A. Bolniški stalež v Kliničnem centru - TOZD Prehrambena služba v letu 1981. In: Modic S ed. Seminar Spremljanje, proučevanje in obvladovanje bolniškega staleža in invalidnosti (prevencija). Ljubljana, Slovenia: UKC, TOZD UIMDPŠ, 1983:30219.

28 Galani E, Kikemenis AX. Absenteeism: a study in a Greek hospital. In: ISSA 6th international symposium on epidemiology and occupational risks, [abstract]. Graz, Austria: Tobelbad, 22-24.April 1998:100.

29 Steide I. Moving patients without damaging one's back: changes in behaviours as a new approach in prevention. In: ISSA 6th international symposium on epidemiology and occupational risks. Abstracts. Graz/Tobelbad, 22-24 April 1998:122.

30 Koselj M. Nadzor kakovosti izvajanja zdravstvenega varstva bolnikov s sladkorno boleznijo. In: Medvešček M, ed. Strokovna izhodišča za nacionalni načrt zdravstvenega varstva bolnikov s sladkorno boleznijo. Ljubljana, Slovenia: October 1995:23-9.

31 Selby J, Thomas G, Zhang D, et al. Excess costs of medical care for patients with diabetes in a managed care population. Diabet Care 1997;20:1396-402.

32 Turtle J. Economics of diabetes care. In: Delice G, ed. Triennial report 1994-7. Brussels: International Diabetes Federation, 1997:15-6.

33 Järvinen HY. Pathogenesis of non-insulin-dependent diabetes mellitus. Lancet 1994;343:91-100.

34 Eschwege E, Simon D, Balkau B. The growing burden of diabetes in the world population. IDF Bulletin 1997;42:149.

35 Jervel J. Why is type 2 diabetes (NIDDM) becoming so common in developing countries? IDF Bulletin 1998;43:67.

36 Reif N. Principi ocjene radne sposobnosti bolesnika od šećerne bolesti. In: Carpeta R, Reif N, Ribarić M, et al, eds. Radna sposobnost $i$ invalidnost. Sveučilište u Zagrebu, Medicinski fakultet u Zagrebu, SIZ mirovinskog i invalidskog osiguravanja radnika Hrvatske, RO “Zrinski” TIZ Cakovec. Cakovec, Zagreb: 1987:169-89.

\title{
Narrative Based Medicine, An Interdisciplinary Conference
}

\author{
Research, Narrative, and Practice
}

A two day conference-Monday 3rd and Tuesday 4th September 2001

Homerton College, Cambridge, UK

\section{BMF Publishing Group}

For full details contact: BMA/BMJ Conference Unit, Tavistock Square, London, WC1H 9JP Tel: +44 (0)207383 6819; fax: +44 (0)207383 6663; email: clyders@bma.org.uk. www.quality.bmjpg.com 